\title{
RESEARCH PAPER \\ Agricultural employment in Spain and new Keynesian economics
}

\author{
Silvia Andrés González-Moralejo, and Mildrey García Cortés \\ International Economics and Development Group. Universidad Politécnica de Valencia, Departamento de \\ Economía y Ciencias Sociales, ETS de Ingeniería Agronómica y Medio Natural. Edificio 3B ( $2^{\circ}$ planta). \\ Camino de Vera, s/n. 46022. Valencia, Spain.
}

\begin{abstract}
S. Andrés, and M. García. 2016. Agricultural employment in Spain and new Keynesian economics. Cien. Inv. Agr. 43(2):191-201. Our research examines the agricultural labor market from the perspective of new Keynesian economics. Our aim is to verify that total gross output, total factor productivity, and real wages act as determinants of employment levels in Spanish agriculture. Three structural econometric models were estimated using census data for the period 1998-2013. This was a period of profound economic and social change, and the following two distinct sub-periods were compared: 1998-2007 (a period of economic boom) and 2008-2013 (a period of recession). The empirical evidence is consistent with neo-Keynesian theoretical posits, albeit with certain qualifiers derived from the specifically rural nature of the evidence. The results show a negative relationship between employment and productivity and wages, which intensified during the recession.
\end{abstract}

Key words: agrarian labor market, neo-Keynesian model, wages.

\section{Introduction}

From an economic standpoint, employment growth may have adverse effects if employment is not productive and stable, more so if productivity and competitiveness are stagnant. Between 1995 and 2007, employment in Spain increased considerably, and this growth was especially intense in sectors with high levels of temporary contraction and low levels of productivity and job skills. Subsequently, from the start of the Great Recession in 2008, a massive destruction of jobs occurred that was much more intense in Spain than in neighboring nations.

Received April 23, 2015.Accepted May 26, 2016. Corresponding author: silangle@upvnet.upv.es
European political thought is dominated by a belief in greater flexibility and wage restraint in response to high levels of joblessness. This view has been reinforced by the Great Recession and the 'euro-crisis'. The following quotation from the Monthly Bulletin of the European Central Bank (August 2012), exemplifies this perspective: 'More significant reductions in unit labor costs are particularly urgent, especially in countries where unemployment is very high. To achieve this it is necessary to make the process of wage determination more flexible by relaxing employment protection legislation, abolishing wage indexation schemes, reducing minimum wages, and allowing wage bargaining at company level...' 
This paper provides an objective view of agricultural employment in Spain by analyzing its development between 1998 and 2013 - a period in which the economy experienced very different economic conditions. This purpose is achieved by a study that fits within the new Keynesian economics (NKE) school of thought and offers an updated and comprehensive research vision. We aim to explain the specific characteristics of agricultural employment in Spain and link these with the assumptions made by new Keynesian economists. The implications of this study are relevant for guiding economic policy decisionmaking and provide a framework for defining public policy strategies aimed at protecting and developing rural employment.

The works of Gray (1976), Fischer (1977) and Taylor $(1979,1980)$ are often cited as close antecedents of new Keynesian economics (NKE); their main novelty is the consideration of the rational expectation hypothesis within a framework of rigid nominal wages. However, the assumption of nominal wage rigidity was soon abandoned and a series of works in various areas have shaped what we now know as NKE. The primary common features can be summarized in the following three points: 1) acceptance of the assumption that markets do not clear out (Blanchard and Kiyotaki, 1987); 2) emphasis on microeconomic foundations (Ball and Romer, 1990); and 3) macroeconomic implications that are often identified with Keynesianism, such as the effectiveness of demand policies (Mankiw, 1988) and involuntary unemployment.

Basically, there are three lines of work within NKE (Caraballo et al., 2000): one based on the goods market; another based on the credit market; and finally, the so-called European NKE, which pays special attention to the job market and which inspires this work.

European NKE theories focus firstly on the analysis of wages as a determinant of employment, which is the core of the Keynesian theory of employment (Keynes, 2005). Secondly, they focus on the existence of involuntary unemployment (Galí, 1996) that is not attributable to voluntary decisions by workers and its relationship to inflation (Mankiw, 2001; Mankiw and Reis, 2002; Galí, 2011); the correlation of which is incorporated into the concept of the Phillips curve. The fundamental Keynesian objection to the classical theory of employment relates to the assumption by the latter that employment is determined only by real wages, regardless of the aggregate demand for goods. As noted by Galí (2013) in his discussion of Keynes' General Theory, the Keynesian point of view can be summarized as follows: employment is determined by real wages, the amount of production that companies are seeking to achieve, and technological change. Accordingly, employment is represented by $\mathrm{L}=\mathrm{f}(\mathrm{Y}, \mathrm{w}, \mathrm{A})$, where the level of employment (L) is explained by the level of production (Y), which has a positive effect on employment and (consistent with the NKE approach) is equivalent to effective demand; wage levels (w) show an inverse relation to employment such that higher real wages correspond to lower levels of employment (Keynes (2005) warned that there comes a time when falling real wages may fail to eradicate involuntary unemployment given the existence of insufficient effective demand); and the productivity of labor and capital, which are incorporated in the concept of total factor productivity (A). Growth in total factor productivity (TFP) causes the level of employment to decline. The new literature on economic growth in the 1990s, led by Paul Romer, associates TFP with the technological level of a country and its progress (Romer, 1998). However, we must not forget the nature of residuals (as will be shown below, TFP is calculated as the residual from GDP growth minus the contributions of capital and labor). As such, TFP captures the influence of the level of training and education of workers as well as the legal framework related to technology, organizational efficiency and the correct allocation of factors of production within a nation (Mankiw, 2014). 
The most recent contributions to European NKE have strengthened its theoretical analysis by adding new social and institutional details, as called for by authors such as Vanees and Garretsen (1993). Jarmolowicz and Knapinska (2011) presented the most recent theories regarding the operation of the labor market in developed countries with an emphasis on mobility and labor flows; they explain imbalances in the labor market from the perspective of insider-outsider theory (this theory separates stable workers (insiders) and unemployed (outsiders).

According to this approach, union action of the insiders to fix minimum wages pushes up wages (which is detrimental to outsiders), and the sociological model of efficiency wages (in which firms do not wish to reduce real wages because this affects the productivity of workers: as information is asymmetric, companies encourage best efforts of the workers by paying high wages. Although this approach raises costs also rise consumption, effort, productivity, skills, and feelings of loyalty to the company) assumes that a lack of flexibility in wage levels is responsible of such imbalances. Dutta (2014) uses the hypothesis of efficiency wages to explain unemployment in skilled and unskilled labor markets. Galí (2013) discusses the role of wages in employment determination from the perspective of the Keynesian model. This analysis highlights the central role of monetary policy in shaping the relationship between wages and employment, and determines the impact of greater wage flexibility on welfare.

From the work of Diamon, Mortensen, and Pissarides (awarded the Nobel Prize in Economics in 2010 for their analysis of labor markets with wage rigidities and friction in job searches), a literature developed that extends the traditional neo-Keynesian model so that it addresses situations of involuntary unemployment due to the existence of rigidities and job search costs. From the well-known work of Mortensen and Pissarides (1994), this research line proposes an alternative framework in which the neo-Keynesian model endogenously reproduces unemployment as a result of the existence of rigidities in the labor market, particularly in the system for setting wages. Wages are presented in the model as a remuneration for work, which under equilibrium conditions would balance the quantity of workers offered by families (number of workers who want to work) with the quantity of workers demanded by firms (number of jobs available). If it were possible to revise wages each period and for each company, a perfect match between labor supplied and demanded would occur, and there would be no unemployment. In contrast, the presence of fixed salaries (not revised each period) explains the differences between the supply of and demand for labor and leads to situations of oversupply (unemployment) when demand shrinks and wages are not revised downwards (similarly, an excess of demand, or overemployment, is generated if demand growth is not accompanied by upward wage revisions). Consequently, the model shows the economic dynamism and inverse relationship between wage inflation and unemployment rates - reminiscent of the original Phillips curve (Casares, 2012).

European NKE theories have been recently applied in the analysis of agricultural labor markets in various regions, including the USA (Fisher and Knutson, 2013); the European Union (Cuerva, 2012); Africa (Oya, 2013); and China (Li et al, 2013; Cai and Du, 2011). The empirical evidence relating to the market for agricultural labor is consistent with NKE, especially with regard to the efficiency wage hypothesis; however, it sometimes disagrees, due to the rural specificity, with results obtained in other sectors of the economy (Moretti and Perloff, 2002).

The general objective of this paper is to analyze the determinants of the level of employment in the Spanish agricultural sector based on the approaches of NKE. This objective implies the need to address the following specific objectives: establish the characteristics of agricultural employment in Spain, examining its development 
between 1998-2013 and making a comparison with other sectors of the economy as well as confirm that total gross agricultural production, changes in total factor productivity, and real wages act as the main determinants of agricultural employment in Spain. According to this theoretical approach, we expect to see a positive relationship between output and employment and a negative relationship between employment and productivity and wages.

\section{Materials and methods}

To test this theory with empirical data available from the agricultural sector, we analyze three structural econometric models estimated using ordinary least squares (OLS). The analysis covers the years 1998-2013, and within that period, we compared two sub-periods, 1998-2007 and 2008-2013. All data are quarterly.

\section{Dependent and independent variables}

Agricultural employment (AE) is considered the dependent variable. Agricultural employment data, measured in thousands, come from the workforce survey of the National Statistics Institute (INE in Spanish), in which the working population is classified by sectors according to activity, occupation, industry, and current status. The independent variables are agricultural production (AP), agricultural wages (AW), and total factor productivity (TFP). Agricultural production data, measured in millions of euros, are obtained from the Statistics Yearbook (2013) published by the Ministry of Agriculture, Food and Environment (MAGRAMA in Spanish).
Constant values for the year 2000 are chosen. Periodically, the MAGRAMA publishes agricultural wage figures and an ordinary general index of agricultural wages. As an approximation of real wages, the general quarterly index of agricultural wages is selected with a baseline of $1985(1 \mathrm{~T} 1985=100)$.

Growth in TFP is measured as a residual between the growth rate in GDP (Y) and the weighted growth rate of aggregate capital (K) and aggregate labor (L) - known as the Solow residual (in recognition of the Nobel Prize winning economist Robert Solow). Its calculation was made following the methodology proposed by Solow (1957), whereby it is possible to obtain the TFP as a residual (designated by (A) in the neo-Keynesian function of employment) such that $\Delta \mathrm{A} / \mathrm{A}=\Delta \mathrm{Y} / \mathrm{Y}$ $-[(\alpha \Delta \mathrm{K} / \mathrm{K})+(\beta \Delta \mathrm{L} / \mathrm{L})]$.

The above equation implies that the increase in production is determined by a proportionate share of the increase in capital $(\alpha)$ and an increase in the labor factor $(\beta)$ plus the contribution made by technological progress. Productivity is calculated as the differential between the value of production and the factor cost. The residual that cannot be assigned directly to any of the factors because it is related to overall employment is termed TFP. These data have been taken from the Report on Structural Indicators of the Spanish Economy and the European Union (Bank of Spain, 2014) published by Eurostat, Ameco, the OECD, and the Bank of Spain. To maintain consistency with the source, TFP is presented as an index with a 1995 baseline $(1 \mathrm{~T} 1995=100)$. Table 1 shows the characteristics of the independent variables and the expected influence of each variable in the analysis.

Table 1. Descriptive statistics, range of variation and expected sign of the influence of the independent variables.

\begin{tabular}{lccccc}
\hline Variable & $\begin{array}{c}\text { Valid } \\
\text { observations }\end{array}$ & Average & $\begin{array}{c}\text { Standard } \\
\text { deviation }\end{array}$ & Range & $\begin{array}{c}\text { Expected } \\
\text { influence }\end{array}$ \\
\hline AP & 60 & $18,592.6$ & 758.78 & {$[17,236.1-19,759.35]$} & + \\
AW & 60 & 311.12 & 45.01 & {$[239.65-372.55]$} & - \\
TFP & 60 & 99.26 & 2.51 & {$[97.2-105.5]$} & - \\
\hline
\end{tabular}


Table 2 shows the linear relationship between each of the variables in the model using a correlation matrix.

Table 2. Correlation matrix.

\begin{tabular}{lcccc}
\hline Variables & AE & AP & AW & TFP \\
\hline AE & 1 & $(-) 0.4142$ & $(-) 0.9449$ & 0.6193 \\
AP & & 1 & 0.2939 & 0.3576 \\
AW & & & 1 & 0.776 \\
TFP & & & & 1 \\
\hline
\end{tabular}

\section{Empirical test}

To estimate the model, we used the SPSS statistical program. Initially, a multivariate analysis of the selected variables was performed, including a review of central tendency, variability, and shape. Of special interest were the bias and standardized kurtosis, which determine whether the sample is from a normal distribution. The presence of multicollinearity was shown using an analysis of the inflation factor of variance. The model below was adjusted and the parameters and statistical significance estimated using the p-value. The statistical significance of the model was tested using ANOVA, and accuracy in estimating the parameters was tested using confidence intervals. Finally, the model was validated by testing the following hypotheses regarding residuals: normal, average value of the residuals, homoscedasticity, and non-correlation between residuals.

The model was tested with three different specifications. For the first specification, we estimated a generic model for 1998-2013. From the graphical representation of the residuals, we observed that it was possible to differentiate two distinct populations within the sample. Indeed, data pertaining to the years 1998-2007 correspond to an economic boom in the Spanish economy, but in 2008 the boom ended, and the nation entered one of the worst recessions in its history; for this reason, the data for the years 2008-2013 correspond to a period of economic crisis. Accordingly, a dummy variable was introduced into the model that enabled us to verify whether the model was affected by the influence of both sub-periods (after a comparative statistical study of the two populations, it is assumed that their variances are equal but that their averages are not - confirming that the years of economic crisis in Spain have affected the development of agricultural employment).

For the second specification, a $\mathrm{Z}$ dummy variable was defined that takes the value 0 for the years 1998-2007 and 1 for the years 2008-2013. The iteration that the $\mathrm{Z}$ variable may have with the other variables in the model was considered. For the third specification, as the bias and the standardized kurtosis of the TFP variable do not belong to the interval $[-2,+2]$, a logarithmic transformation was applied to the model to determine if the relationship could be improved.

\section{Results}

\section{Employment in Spain and agricultural employment}

The year 1998 marked a milestone in the Spanish economy, with integration in the European Monetary Union and its single currency - the euro. By 1998, the recession that had hit the economy between 1993 and 1995 had faded, and a new bullish economic cycle had started that lasted until 2007. It was a decade of economic boom that enabled the creation of more than seven million jobs (Figure 1). These jobs were concentrated mainly in the construction and services sectors, and many were taken by women and immigrants (at the time, both groups were being increasing absorbed into the Spanish labor market).

The economy turned downwards in the last quarter of 2007, although it was not until mid-2008 that an economic recession was officially declared. The recession was linked to the international financial crisis; the rise in energy and commodity prices; and the collapses of the housing market, construction sector, and Spanish financial sector. 


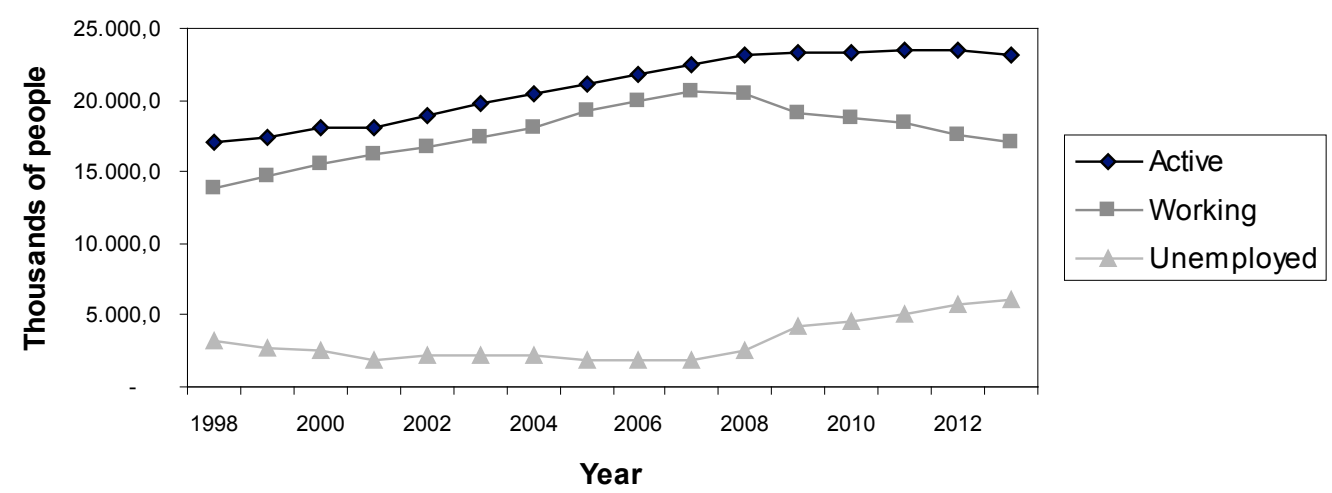

Figure 1. Employment in Spain, 1998-2013 (García, 2013).

The recession immediately produced massive job losses in all regions, and men over 45 and under 25 years of age were hardest hit. The national jobless rate grew exponentially from 8.5 percent in the last quarter of 2007 to 25.7 percent in the last quarter of 2013, the highest unemployment rate in the history of Spanish democracy and more than double the figure for the European Union according to Eurostat. Growth in industrial exports, labor-intensive harvests, the return of foreigners to their home countries, and an outward migration of Spanish workers (usually highly qualified) to other countries in search of a jobs, was not enough to overturn the stagnation in GDP and a significant contraction in consumption and investment. Moreover, the government reformed labor legislation in 2010 and 2012, undermining the power of collective bargaining and lowering the cost of redundancy.

Table 3 shows how employment has varied in various sectors during the study period. The service sector accounts for more than two-thirds of employment, demonstrating how much the tertiary sector has grown in the Spanish economy (service sector jobs reached 76 percent in 2013). Undoubtedly, this is the sector in which employment has remained most stable during the economic downturn, with a loss of only five percentage points between 2007 and 2013. The service sector is followed by the industrial sector (with an average employment share of 17 percent - but falling) and then by the construction sector (with an average 10.5 percent share thanks to the housing bubble between 1998 and 2007). Construction lost 62 percent of its jobs between 2007 and 2013 after the housing bubble burst.

The evolution of agricultural employment has not followed the same logic, and the tendency has been towards constant contraction. In 1970, some 25 percent of Spain's active population worked in agriculture, while the figure was 8 percent at the beginning of the study period and had fallen to just 4.3 percent by 2013. This situation is intrinsic to economic development, as the primary sector gradually loses importance in terms of GDP in favor of other areas of the economy. As demand for agricultural labor decreases in rural areas, the remaining workers assume new functions in conservation and the provision of public goods. Not even the EU Common Agricultural Policy, of which Spain was the second largest beneficiary during the study period, was able to reverse this trend.

During the study period, the agrarian labor market was seasonal in nature, with differing levels of demand for workers reflecting the varying crops and production techniques, and the market 
Table 3. Employment in Spain according to sector, 1998-2013 (thousands of jobs).

\begin{tabular}{lrrrrr}
\hline Year & Total occupied & Agriculture & Industry & Construction & Services \\
\hline 1998 & 13,904 & 1,085 & 2,858 & 1,385 & 8,576 \\
1999 & 14,690 & 1,048 & 2,958 & 1,572 & 9,111 \\
2000 & 15,506 & 1,029 & 3,083 & 1,723 & 9,672 \\
2001 & 16,146 & 1,045 & 3,177 & 1,876 & 10,048 \\
2002 & 16,630 & 995 & 3,191 & 1,980 & 10,464 \\
2003 & 17,296 & 991 & 3,201 & 2,102 & 11,003 \\
2004 & 17,971 & 989 & 3,211 & 2,253 & 11,518 \\
2005 & 18,973 & 1,001 & 3,280 & 2,357 & 12,335 \\
2006 & 19,748 & 944 & 3,292 & 2,543 & 12,968 \\
2007 & 20,580 & 929 & 3,287 & 2,703 & 13,660 \\
2008 & 20,470 & 828 & 3,237 & 2,460 & 13,945 \\
2009 & 19,107 & 788 & 2,808 & 1,890 & 13,621 \\
2010 & 18,725 & 786 & 2,650 & 1,651 & 13,637 \\
2011 & 18,421 & 755 & 2,605 & 1,404 & 13,658 \\
2012 & 17,633 & 743 & 2,484 & 1,161 & 13,244 \\
2013 & 17,139 & 737 & 2,356 & 1,030 & 13,018 \\
\hline
\end{tabular}

Source: Labour Force Survey (INE).

showed a marked geographical concentration in production. The absence of closed labor markets distinguishes the industry, with jobs created in specific places during varying periods - causing a seasonal migration that requires a flexible labor force with geographic and temporal mobility. This situation means that agricultural labor tends to be low-skilled, and there is an emphasis on immigrant labor and illegal cash in-hand work. According to figures from the Ministry of Employment and Social Security, work permits granted to immigrants increased from 18,600 in 1998 to 42,500 in 2013, and they reached a peak of 134,600 in 2005 . There has been a relative aging of the employed population in agriculture compared to other sectors - with greater male involvement and a large share of part-time work.

\section{Determinants of agricultural employment}

Table 4 shows the main results of the various specifications of the estimated model. The first column shows the generic model, including only those variables for which significant parameters were obtained in the tests conducted, with the application of a Cochrane-Orcutt transformation to correct the serial correlation found between the residuals. The second column shows the results obtained when the $\mathrm{Z}$ dummy was introduced into the model and the insignificant independent variables were eliminated. Finally, the third column shows the logarithmic model with the dummy variable (that which provides the best fit after various tests) and includes only the significant variables.

The results are generally consistent with the established hypothesis. In specification 1, a negative and significant relationship is found between the AW and TFP independent variables and the AE independent variable, indicating that the higher the AW and TFP, the lower the volume of agricultural employment. Thus, a unit increase in wages causes a decrease of 3,454 units of employment, and a unit increase in TFP produces a decrease of 10,761 units of employment. The results of the second specification, which provides a better fit than the previous one, show wages to be the only explanatory variable for employment in the agricultural sector. During the years of economic boom $(Z=0)$, a unit of wage increase caused a decrease of 1,310 units of employment. 
Table 4. Determinants of agricultural employment.

\begin{tabular}{lccc}
\hline $\begin{array}{l}\text { Explanatory } \\
\text { variables }\end{array}$ & $\begin{array}{c}\text { Specification 1 } \\
\text { Generic model }\end{array}$ & $\begin{array}{c}\text { Specification 2 } \\
\text { Model with dummy }\end{array}$ & $\begin{array}{c}\text { Specification 3 } \\
\text { Logarithmic model }\end{array}$ \\
\hline CONSTANT & 773.198 & 346.078 & 2.265 \\
AP & - & - & - \\
AW & -3.454 & -1.31 & - \\
TFP & -10.761 & - & - \\
Z*AW & - & -0.353 & - \\
LOG(AW) & - & - & -0.379 \\
$Z^{*}$ LOG(AW) & - & - & -0.028 \\
$\mathrm{R}^{2}$ & 83.391 & 98.006 & 97.708 \\
$\mathrm{R}^{2}$ adjusted & 80.371 & 97.674 & 97.326 \\
Standard error & $1.822(\mathrm{P}=0.180)$ & $2.654(\mathrm{P}=0.790)$ & $1.586(\mathrm{P}=0.083)$ \\
Mean absolute error & 25.498 & 17.902 & 0.021 \\
Durbin-Watson & 18.138 & 13.906 & 0.017 \\
\hline
\end{tabular}

Level of significance: $\mathrm{P} \leq 0.05$.

However, during the recession, a difference of -0.353 is detected in the average increase of the $\mathrm{AE}$ variable in comparison with the boom years (i.e., if $Z=1$, then the contractionary effect exerted by wages on employment intensifies, and a unit increase in wages causes a decrease of 1,663 units of employment). Finally, the logarithmic or third specification of the model does not provide a better fit but confirms the role of wages as a determinant of employment. The elasticity of employment with respect to wages is -0.379 in times of economic expansion, i.e., if $Z=0$, then if wages increase by 1 percent the $\mathrm{AE}$ is reduced by 0.379 percent. During the economic recession period $(Z=1)$, a difference of -0.028 appears in the expected percentage increase in the value of $\mathrm{AE}$ compared with the growth years; therefore, elasticity is measured at -0.407 .

\section{Discussion}

In recent decades, Spanish agriculture has steadily but rapidly reduced the use of labor. The economic crisis present since 2008 has accelerated this trend. However, the transfer of labor to other economic activities has been losing weight as a factor in explaining the decline in agricultural employment, while greater prominence has been given to factors such as mechanization, retirement, and the abandonment of certain activities (Andrés et al., 2013). A feature of agricultural employment that has maintained a certain independence from time is its strong family tradition, and recent developments point to a slight upturn in the numbers being employed - including an increasing number of immigrant workers. In this paper, we have analyzed the determinants of employment in the Spanish agricultural sector based on the theoretical approach of new Keynesian economics. We have examined whether total gross agricultural production and changes in total factor productivity and wages are major determinants of agricultural employment. According to this theoretical approach, we expected to find a positive relationship between output and employment and a negative relationship between employment and productivity and wages. We used census data from the Agricultural and Food Statistics Yearbook published by the Ministry of Agriculture, Food, and Environment and the National Institute of Statistics to estimate (using ordinary least squares) three structural econometric models for 1998-2013 and compare two sub-periods: 1998-2007 (economic growth) and 2008-2013 (recession). The results from the econometric analysis enabled us to reach the following conclusions: 
1. The Keynesian principle that employment depends on what firms produce and their production levels (which in turn depend on what consumer buy, or aggregate expenditure) has not been fulfilled in Spanish agriculture. The AP variable is insignificant in all estimated models. Ultimately, agricultural production depends on uncontrollable external factors and the climate, which can cause fluctuations in production in very short periods of time. Several factors have favored the existence of illegal or illicit work and reduced the mobility of agricultural production factors such as the following: the fact that a high percentage of farm work is undertaken by the landowner and his or her family; temporary employment is common in the sector (due to the seasonality and geographical concentration of crops) and production costs are increasing. For these reasons, a growth in production may be insufficient to support growth in agricultural employment (as quantified in official statistics).

2. According to the generic model estimation, the expected influence of AW and TFP is confirmed. This result demonstrates the basic premise of NKE, according to which the evolution of the labor market is the result of wage levels (hence the importance of this approach in considering minimum wages, collective agreements, and efficiency wages as the factors mainly responsible for the evolution of the labor market and its tendency toward involuntary unemployment) as well as increases in technology, organizational efficiency, and economies of scale (TFP), variables that have a contractionary effect on the level of agricultural employment. Our results suggest that a unit increase in wages will generate a decline in agricultural employment of 3.45 units, while a unit increase in TFP will cause a decrease in employment of 10.76 units.

3. The estimation with the dummy variable (which divides the sample data into two populations, one belonging to a boom and the other a recession) was the estimation with the best statistical fit given that TFP loses its significance and the AW variable remains as the only explanatory variable. This result suggests that agricultural employment in Spain is basically determined by wages. For agricultural entrepreneurs, wage levels seem to be the primary factor to be taken into account given the already described characteristics of the agrarian labor market and the fact that other labor costs generated by the workforce (such as redundancy payments and training) are less relevant to this sector than to other sectors of the economy. The implications of this result invite reflection on the role of the minimum wage and the presence of agricultural unions (Union of Small Farmers and Ranchers, Coordinator of Farmers and Ranchers Organisations), whose actions may further decrease the level of agricultural employment.

4. Another important finding of the dummy variable results is that the effect of wages on agricultural employment is lower in times of economic growth, with a coefficient of -1.31 (a one-unit wage increase will cause a decrease in employment of 1.31 units), but intensifies during a recession, with the coefficient rising to -1.66 (a one-unit wage increase will cause a decline in sector employment of 1.66 units). Agricultural employers are more sensitive to increases in wages when deciding to hire workers during a recession or period of economic stagnation. Agricultural unemployment reached record levels during the latter years of the study period, and a new trend points to a reduction in the number of immigrants available to work in agriculture (due to returning to their home countries), while the number of Spanish workers available for agricultural work has increased (caused by the lack of opportunities in other sectors of the economy).

5. The above findings are repeated in the results obtained with the logarithmic specification. The main contribution is the finding that the variation in agricultural employment in Spain is inelastic to changes in wages: when wages increase by 1 percent, employment decreases by 0.38 percent. As expected, the percentage of contraction also intensifies during periods of economic crisis: 
whenever wages have increased by 1 percent since 2008, the result has been a reduction in employment of 0.41 percent.

6. The results of this study suggest that wages are the key variable in agricultural employment in Spain. Because wages in the sector have fallen since 2013 (as is clear from recent data published by the National Statistics Institute), the model estimates an increase in the level of employment. However, the results should be interpreted with caution because the relationships that arise in this model may not be causal, and although it seems clear that higher wages push employment levels downward, lower wages do not guarantee an increase in employment because other factors may be at play given the general state of the economy and the specifically rural nature of the populations studied.

\title{
Resumen
}

\begin{abstract}
S. Andrés y M. García. 2016. Empleo agrícola en España y Nueva Economía Keynesiana. Cien. Inv. Agr. 43(2):191-201. La investigación relaciona el mercado de trabajo agrícola con la escuela de pensamiento Nueva Economía Keynesiana. Su propósito es comprobar que la producción bruta, la productividad total factorial y los salarios actúan como determinantes del empleo en la agricultura española. A partir de datos censales se estiman tres modelos econométricos de carácter estructural en un periodo de profundos cambios dentro del contexto económico y social, 1998-2013, por lo que se comparan dos subperiodos distintos, 19982007 y 2008-2013, de auge y recesión económica respectivamente. La evidencia empírica es, en general, consistente con los postulados teóricos neokeynesianos, aunque con ciertas matizaciones derivadas de la especificidad rural. Así, los resultados revelan una relación negativa entre el empleo y la productividad y los salarios, que se intensifica durante los años de contracción de la economía.
\end{abstract}

Palabras clave: Mercado de trabajo agrícola, modelo neokeynesiano, salarios.

\section{References}

Andrés, S., J.M. García, and R. Compés. 2013. A Scenario for the conversion of common agricultural policy payments in Spain after the 2011 legislative Proposals. Ciencia e Investigación Agraria 40:291-306.

Ball, L., and D. Romer. 1990. Real rigidities and the non-neutrality of money. Review of Economic Studies 57:183-203.

Bank of Spain. 2014. Informe de Indicadores Estructurales de la Economía Española y la Unión Europea. Eurostat, Ameco, OECD y Banco de España, Madrid, España.

Blanchard, O.J., and N. Kiyotaki. 1987. Monopolistic competition and the effects of aggregate demand. American Economic Review 77:647-666.
Cai, F., and Y. Du. 2011. Wage increases, wage convergence and the lewis turning point in China. China Economic Review 22:601-610.

Caraballo, M.A., M.A. Galindo, and C. Usabiaga. 2000. La Relación entre la nueva economía Keynesiana y la economía Postkeynesiana: una interpretación. Boletín Económico de ICE 2658:13-21.

Casares, M. 2012. Determinantes del desempleo en el modelo Neokeynesiano: Costes de búsqueda versus rigideces salariales. Revista de Occidente 370:130-132.

Cuerva, M.C. 2012. Determinants of labour productivity convergence in the European agricultural sector. Agrociencia 46:621-635.

Dutta, P.B. 2014. Skilled-unskilled wage inequality, product variety and unemployment: a static 
general equilibrium analysis. Journal of International Trade \& Economic Development 23:3155.

European Central Bank. 2012. Monthly Bulletin, August, Francfort, Germany. Available online at: http://www.bde.es/f/webbde/SES/Secciones/ Publicaciones/PublicacionesBCE/BoletinMensualBCE/12/Fich/bm1208.pdf (Website accessed: May 31, 2014).

Fischer, S. 1977. Long-term contracts, rational expectations and the optimal money supply rule. Journal of Political Economy 85:191-205.

Fisher, D.U., and R.D. Knutson. 2013. Uniqueness of agricultural labour markets. American Journal of Agricultural Economics 95:463-469.

Galí, J. 1996. Unemployment in dynamic general equilibrium economies. European Economic Review 40: 839-845.

Galí, J. 2011. The return of the wage Phillips curve. Journal of the European Economic Association 9:436-461.

Galí, J. 2013. Notes for a new guide to Keynes (I): Wages, aggregate demand and employment. Journal of the European Economic Association 11:973-1003.

García, J. 2013. Lecciones de Economía Española. Thomson Reuters. $11^{\circ}$ ed. Madrid, España.

Gray, J.A. 1976. Wage indexation: a macroeconomic approach. Journal of Monetary Economics 2:221-235.

Jarmolowicz, W., and M. Knapinska. 2011. Labour market theories in contemporary economics. Transformations in Business \& Economics 10 (2A):268-280.

Keynes, J.M. 2005. Teoría General de la Ocupación, el Interés y el Dinero. Fondo de Cultura Económica. $4^{\circ}$ ed. Madrid, España.

Li, Q., J.K. Huang, R.F. Luo, and C.F. Liu. 2013. China's labour transition and the future of China's rural wages and employment. China \& World Economy 21(3):4-24.
Mankiw, N.G. 1988. Imperfect competition and the Keynesian cross. Economics Letters 26:7-14.

Mankiw, N.G. 2001. The inexorable and mysterious trade-off between inflation and unemployment. Economic Journal 111(471):45-61.

Mankiw, N.G., and R. Reis. 2002. Sticky information versus sticky prices: a proposal to replace the new Keynesian Phillips curve. Quarterly Journal of Economics 117:1295-1328.

Mankiw, N.G. 2014. Macroeconomía. In: Bosch A. (ed.). $8^{\circ}$ ed. Barcelona, España.

Moretti, E., and J.M. Perloff. 2002. Efficiency wages, deferred payments and direct incentives in agriculture. American Journal of Agricultural Economics 84:1144-1155.

Mortensen, D.T., and C.A. Pissarides. 1994. Job creation and job destruction in the theory of unemployment. Review of Economic Studies 61:397415.

Oya, C. 2013. Rural wage employment in Africa: Methodological issues and emerging evidence. Review of African Political Economy 40(136):251-273.

Romer, P.M., G. Evans. and S. Honkapohja. 1998. Growth cycles. American Economic Review 88:495-516.

Statistics Yearbook. 2013. Ministerio de Agricultura, Alimentación y Medio Ambiente, Madrid, España. Available online at: http://www.magrama. gob.es/es/estadistica/temas/publicaciones/ anuario-de-estadistica/default.aspx (Website accessed: April 10, 2014).

Taylor, J.B. 1979. Staggered wage setting in a macro model. American Economic Review 69:108-113.

Taylot, J.B. 1980. Aggregate dynamics and staggered contracs. Journal of Political Economy 88:1-23.

Vanees, H., and H. Garretsen. 1993. How to derive Keynesian results from $1^{\text {st }}$ principles. A survey of new Keynesian economics. Economist 141:323352. 
